\title{
A walk on the wild side: gut bacteria fed to mass-reared larvae of Queensland fruit fly [Bactrocera tryoni (Froggatt)] influence development
}

Lucas Alexander Shuttleworth ${ }^{1,2}$, Mohammed Abul Monjur Khan ${ }^{1,3}$, Terrence Osborne $^{1}$, Damian Collins ${ }^{1}$, Mukesh Srivastava ${ }^{1}$ and Olivia Louise Reynolds ${ }^{1,4,5,6^{*}}$

\begin{abstract}
Background: The Queensland fruit fly, Bactrocera tryoni (Froggatt) (Diptera, Tephritidae) is the most significant insect pest of Australian horticulture. Bactrocera tryoni is controlled using a range of tools including the Sterile Insect Technique (SIT). Mass-rearing and irradiation of pupae in SIT can reduce the fitness and quality of the released sterile insects. Studies have also showed reduced microbial gut diversity in domesticated versus wild tephritids.

Results: Transmission electron microscopy confirmed the presence of the bacterial isolates in the mid-gut of massreared larvae, and plate counts from individual larval guts showed increased numbers of bacteria in supplemented larvae. Several developmental and fitness parameters were tested including larval development time (egg-hatch to pupation), pupal weight, emergence, flight ability, sex-ratio, and time to adult eclosion (egg-hatch to adult eclosion). Enterobacter sp. and Asaia sp. shortened larval development time, while this was delayed by Lactobacillus sp., Leuconostoc sp. and a blend of all four bacteria. The mean time from egg hatch to adult eclosion was significantly reduced by Leuconostoc sp. and the blend for males and females, indicating that the individual bacterium and consortium affect flies differently depending on the life stage (larval or pupal). There was no impact of bacterial supplemented larvae on pupal weight, emergence, flight ability, or sex ratio.

Conclusions: Our findings show that bacteria fed to the larval stage of $B$. tryoni can impart fitness advantages, but the selection of probiotic strains (individual or a consortium) is key, as each have varying effects on the host. Bacteria added to the larval diet particularly Leuconostoc sp. and the blend have the capacity to reduce costs and increase the number of flies produced in mass-rearing facilities by reducing time to adult eclosion by 1.3 and 0.8 mean days for males, and 1.2 and 0.8 mean days for females.
\end{abstract}

Keywords: Asaia, Enterobacter, Lactobacillus, Leuconostoc, Sterile insect technique, Area wide - integrated Pest management, Probiotic, Tephritidae, Diptera

\footnotetext{
* Correspondence: oreynolds@cesaraustralia.com

${ }^{1}$ Biosecurity and Food Safety, New South Wales Department of Primary

Industries, Elizabeth Macarthur Agricultural Institute, Menangle 2568, Australia

${ }^{4}$ Graham Centre for Agricultural Innovation (an alliance between NSW

Department of Primary Industries and Charles Sturt University), Wagga

Wagga, New South Wales 2650, Australia

Full list of author information is available at the end of the article
}

(c) The Author(s). 2019 Open Access This is an open access article distributed under the terms of the Creative Commons Attribution IGO License (https://creativecommons.org/licenses/by/3.0/igo/) which permits unrestricted use, distribution, and reproduction in any medium, provided appropriate credit to the original author(s) and the source is given. 


\section{Background}

The Queensland fruit fly, Bactrocera tryoni Froggatt (Diptera, Tephritidae) is native to Australia, and is a pest and biosecurity threat to its $\$ 9$ billion horticultural industry [1]. Bactrocera tryoni is controlled using a range of tools including the Sterile Insect Technique (SIT). SIT involves area-wide, inundative releases of irradiated, i.e. sterile insects to reduce reproduction in a wild population of the same species [2]. Domestication, massrearing and irradiation of pupae impact the quality of larvae and adult flies [3]. They also impact the tephritid gut microbiome, with flow on effects to physiology, behaviour and fitness [4].

Gut bacteria in particular have been recognised for their effects on the physiology of tephritids across all the developmental phases from egg to adult. These include increased larval weight of flies produced from surface sterilised eggs vs non-surface sterilised eggs [5], reduced larval development time [6], increased pupal weight [7, 8], larger males [8], preference of females to mate with bacteria fed males [9], improved male performance [10, $11]$, increased female fecundity [12], increased longevity $[7,8,11,13,14]$, overcoming plant host defences [15], and insecticide resistance [16]. In addition to positive effects on tephritids that have been fed bacteria, there are also reported negative effects such as reduced pupation [17], decreased longevity of males [12], or neutral effects [6]. The majority of previous studies have focused on feeding bacteria to adults, resulting in limited information on the effects of bacterial supplementation at the larval stage. Furthermore, larval studies have predominantly focused on the family Enterobacteriaceae, likely due to the dominance of this family in the gut of several tephritids [4]. For example, a study feeding a blend of three enteric bacteria Citrobacter freundii, Enterobacter sp., and Klebsiella pneumonia to mass-reared Mediterranean fruit fly, Ceratitis capitata Wiedemann larvae (where male pupae were subsequently irradiated under SIT), showed increased male and female pupal weight, larger sized males, increased lab survival under stress, and enhanced male sexual performance [8]. Another enteric bacterial species, Klebsiella oxytoca increased mating competiveness of bacterial supplemented sterile adult male $C$. capitata for wild females against wild males, inhibited female receptivity more efficiently than sugar only fed males, and increased survival under stress [11]. A study that fed a single strain of Enterobacter sp. to $C$. capitata larvae reduced male larval development time, however did not impact pupal weight, flight ability, laboratory survival under stress, or mating competitiveness [6]. Enterobacter sp. was also a target probiotic fed to larvae of Zeugodacus cucurbitae Coquillett (melon fly) with significant increases in pupal weight, survival rate, and size of flies were significantly increased [7].
Although Enterobacteriaceae are dominant in several tephritids, other bacterial groups may play crucial roles [4]. Further research is therefore warranted to test the effects of feeding a greater diversity of bacterial strains to the larval stage.

The aims of the current study were to test the effects of bacteria sourced from wild larval B. tryoni and fed to mass-reared larvae, on larval development and several standard quality control parameters of the larval, pupal and adult stages used in SIT programs [18].

\section{Results \\ Phylogenetic identification of wild $B$. tryoni bacterial candidates using 16S rRNA}

Phylogenetic analyses indicated that each bacterial strain isolated from the wild B. tryoni gut (Asaia sp. DAR 83288, Enterobacter sp. DAR 83287, Lactobacillus sp. DAR 83289 and Leuconostoc sp. DAR 83290) and utilised as a larval probiotic in this study, clustered with Asaia sp., Enterobacter sp., Lactobacillus sp. and Leuconostoc sp. clades respectively in the $16 \mathrm{~S}$ rRNA maximum parsimony phylogeny (Fig. 1).

\section{Quantification of bacterial cells in guts of mass-reared larvae fed wild bacteria}

The mean number of colony forming units, isolated from third instar B. tryoni larvae, of each bacteria were higher than the control in both the supplemented individual and blend bacterial groups (all $\mathrm{df}=12$, Asaia sp.: $\mathrm{F}=122.6, p<0.001$; Enterobacter sp.: $\mathrm{F}=3282 ; p<0.001$; Lactobacillus sp.: $\mathrm{F}=247.7 ; p<0.001$;), although this was not significant for Leuconostoc sp. $(\mathrm{F}=3.17$; $\mathrm{df}=12 ; p=$ 0.078) (Table 1).

\section{Transmission electron microscopy of mass-reared larvae fed wild bacteria}

The bacteria provided to larval B. tryoni were visualised with transmission electron microscopy (Fig. 2), illustrating the presence of the bacteria within the third larval instar midguts after supplementation in the carrot diet.

\section{Larval development time}

All bacterial supplemented larvae had significantly lower or higher larval development time (LDT) than the control $(\mathrm{df}=55 \mathrm{~F}=74.1 p<0.001)$. Enterobacter $\mathrm{sp}$. and Asaia sp. reduced LDT, while Lactobacillus sp., Leuconostoc sp. and the blend delayed this parameter (Fig. 3). Asaia sp. and Enterobacter sp. supplemented larvae had a mean LDT of 7.53 and 7.33 days, while Lactobacillus sp., Leuconostoc sp. and the blend supplemented had a mean LDT of $8.24,8.86$ and 8.43 days respectively. 


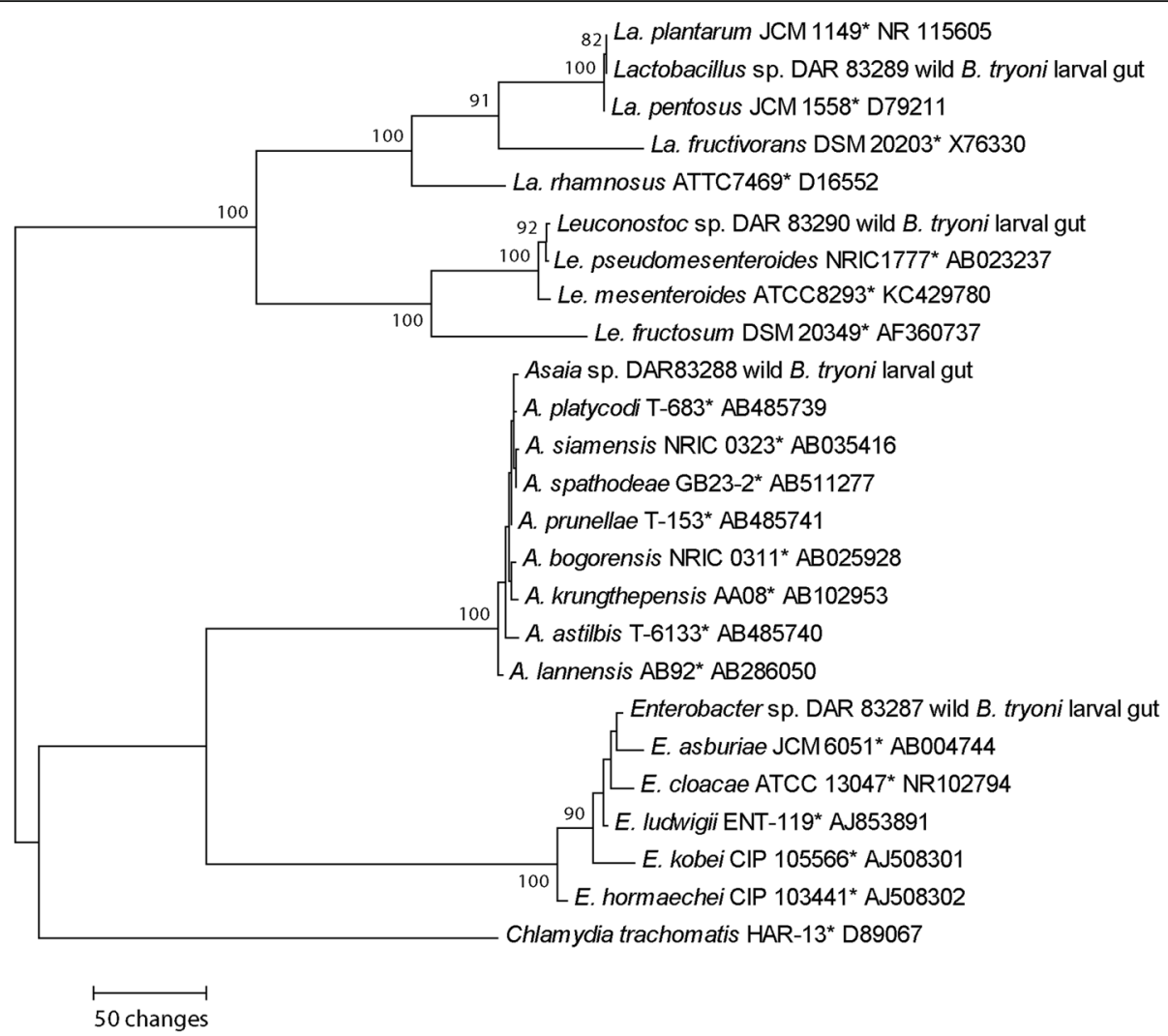

Fig. 1 Maximum parsimony phylogeny using $16 \mathrm{~S}$ rRNA sequences including wild bacterial candidates isolated from wild B. tryoni larval midguts, and fed to mass-reared larvae. Chlamydia trachomatis was selected as the outgroup. Maximum parsimony bootstrap supports $\geq 70 \%$ are placed on branch nodes. ${ }^{*}$ indicates type culture. Culture and GenBank accessions are listed next to isolates

Table 1 The mean colony forming units isolated from individual mass-reared third instar larvae after feeding various bacteria supplements in the larval diet

\begin{tabular}{lll}
\hline $\begin{array}{l}\text { Bacterial group/combination fed } \\
\text { to mass-reared larvae }\end{array}$ & $\begin{array}{l}\text { Mean colony forming } \\
\text { units per larva }\end{array}$ & $\begin{array}{l}\text { Standard } \\
\text { error }\end{array}$ \\
\hline $\begin{array}{l}\text { Individual } \\
\text { Asaia sp. }\end{array}$ & 219,680 & 11,969 \\
Enterobacter sp. & 244,960 & 5653 \\
Lactobacillus sp. & 9980 & 2560 \\
Leuconostoc sp. & 18,720 & 14,071 \\
Blend & & \\
Asaia sp. & 21,120 & 13,228 \\
Enterobacter sp. & 205,200 & 9156 \\
Lactobacillus sp. & 77 & 12 \\
Leuconostoc sp. & 9328 & 2194 \\
Control (no added bacteria) & & \\
Asaia sp. & 45 & 5 \\
Enterobacter sp. & 1603 & 122 \\
Lactobacillus sp. & 4 & 1 \\
Leuconostoc sp. & 3236 & 1502 \\
\hline
\end{tabular}

\section{Pupal weight}

Pupal weight did not differ between the bacterial groups (Fig. 4; $\mathrm{df}=25 \mathrm{~F}=1.97 p=0.118$ ). However, the mean pupal weight of $B$. tryoni supplemented with the bacteria were all lighter than the control (mean individual pupa weight of $11.67 \mathrm{mg}$ ), with the lightest pupae those supplemented with Lactobacillus sp. (mean individual pupa weight of $10.52 \mathrm{mg}$ ).

\section{Adult eclosion}

All bacteria supplemented B. tryoni larvae had a reduced mean period from egg hatch to adult eclosion in both males and females compared with the control (Figs. 5 and 6). The fastest eclosing B. tryoni males were those supplemented with Leuconostoc sp. or the blend, with the mean period from egg hatch to adult eclosion 22.6 days and 23.1 days respectively, compared to 23.9 days for the control males $(\mathrm{df}=25, \mathrm{~F}=6.1$ Leuconostoc sp. $p<0.001$, blend $p<0.01$ ). The fastest eclosing B. tryoni females were also those supplemented with Leuconostoc sp. or the blend with 22.8 and 23.2 days respectively, compared to 24 days for the control females $(\mathrm{F}=7.13$ Leuconostoc sp. $p<0.001$, blend $p<0.01$ ). 


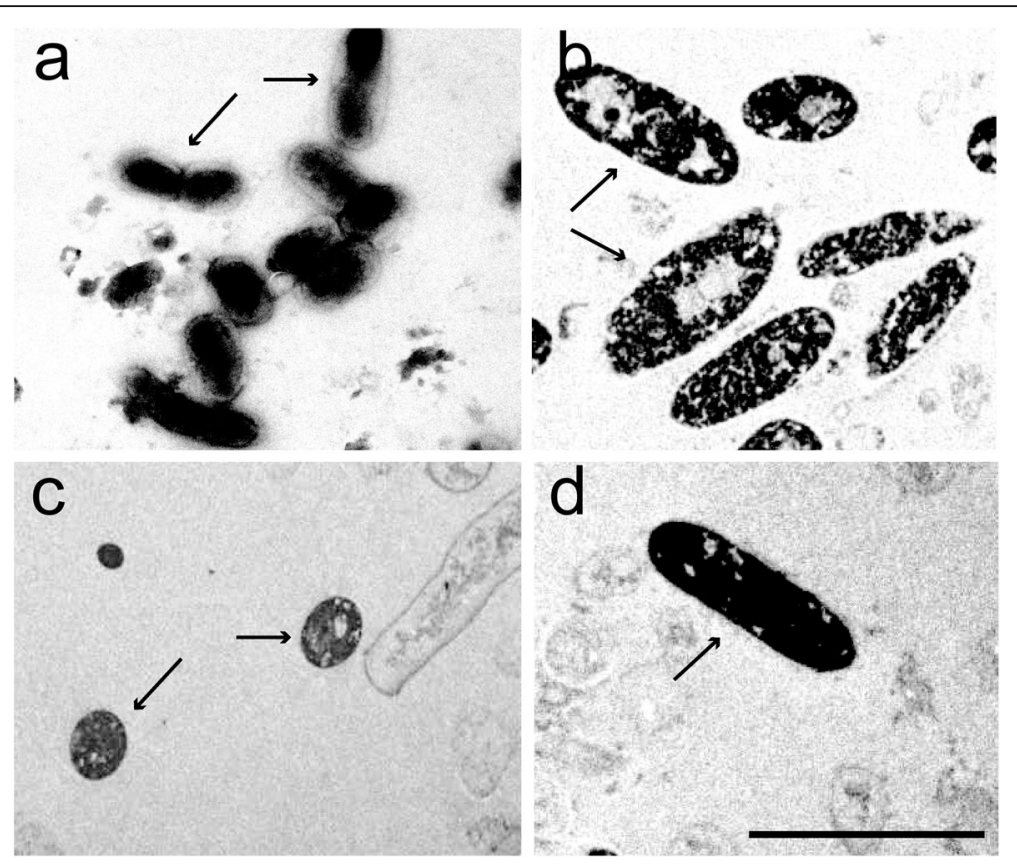

Fig. 2 Transmission electron micrographs of bacterial cells after feeding to mass-reared $B$. tryoni larvae. $\mathbf{a}=$, Asaia sp. cells, $\mathbf{b}=$ Enterobacter $\mathrm{sp}$. cells, $\mathbf{c}=$ Leuconostoc sp. cells, $\mathbf{d}=$ Lactobacillus sp. cell. Arrows indicate cells from the specific strains. Scale $=5 \mu \mathrm{m}$

\section{Emergence}

The mean number of bacteria supplemented emerged adult B. tryoni did not differ to the control $(\mathrm{df}=25 \mathrm{~F} 1.09$ $p=0.390)$. All bacterial groups had mean emergence $\geq 95 \%$ (Table 2).

\section{Flight ability}

The mean flight ability of adult $B$. tryoni supplemented with bacteria did not differ to the control $(\mathrm{df}=25 \mathrm{~F}=$ $0.956 p=0.463)$. Mean flight ability was $\geq 91 \%$ for all bacterial groups (Table 2).

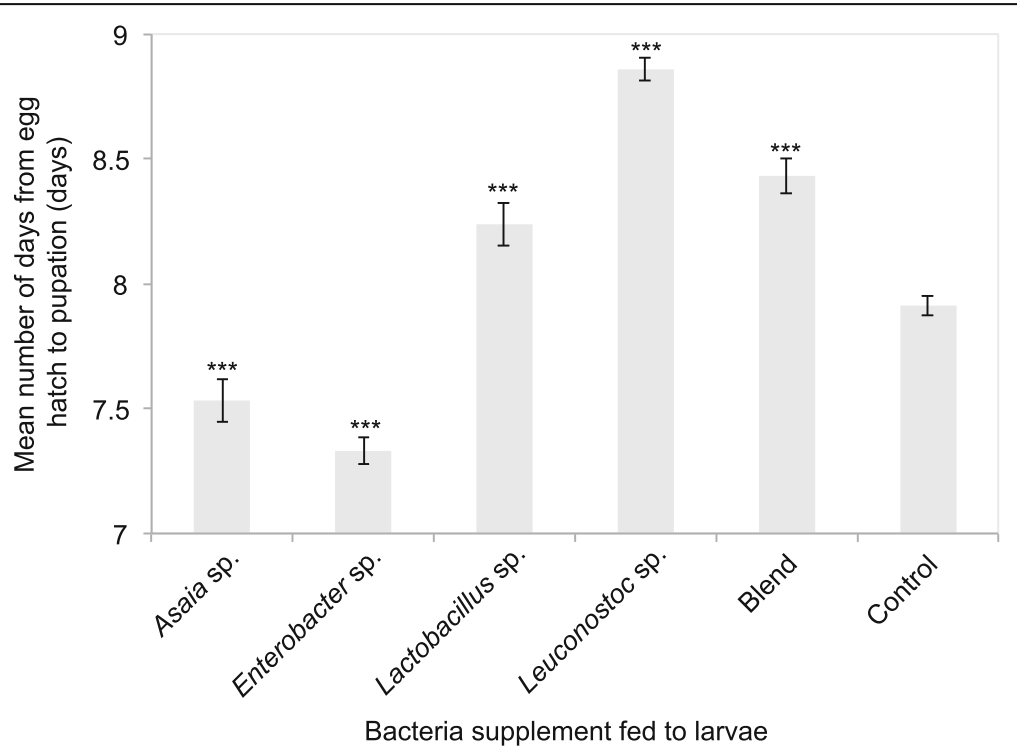

Fig. 3 Time (days) from egg hatch to pupation (larval development) of B. tryoni larvae supplemented with various wild bacteria. Error bars indicate standard error of the mean. Asterixes above columns indicate if the bacterial group is significantly different to the control and the respective $p$-value $\left(\mathrm{df}=55,{ }^{*} p<0.05,{ }^{* *} p<0.01,{ }^{* *} p<0.001\right)$ 


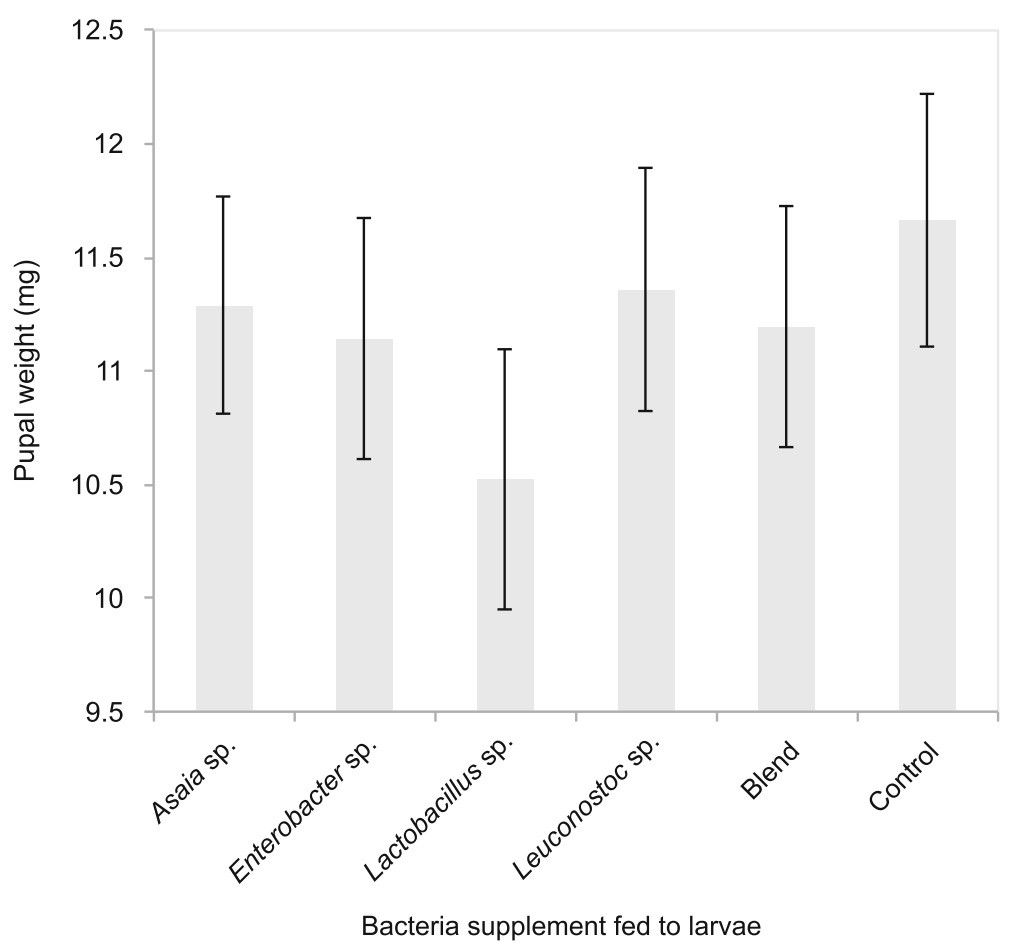

Fig. 4 Mean pupal weight of mass-reared B. tryoni larvae supplemented with bacteria isolated from wild B. tryoni larvae. Error bars indicate standard error of the mean. The ANOVA showed there were no significant difference of pupal weight between the bacterial groups fed to larvae and the control $(F=1.97, \mathrm{df}=25, p=0.118)$

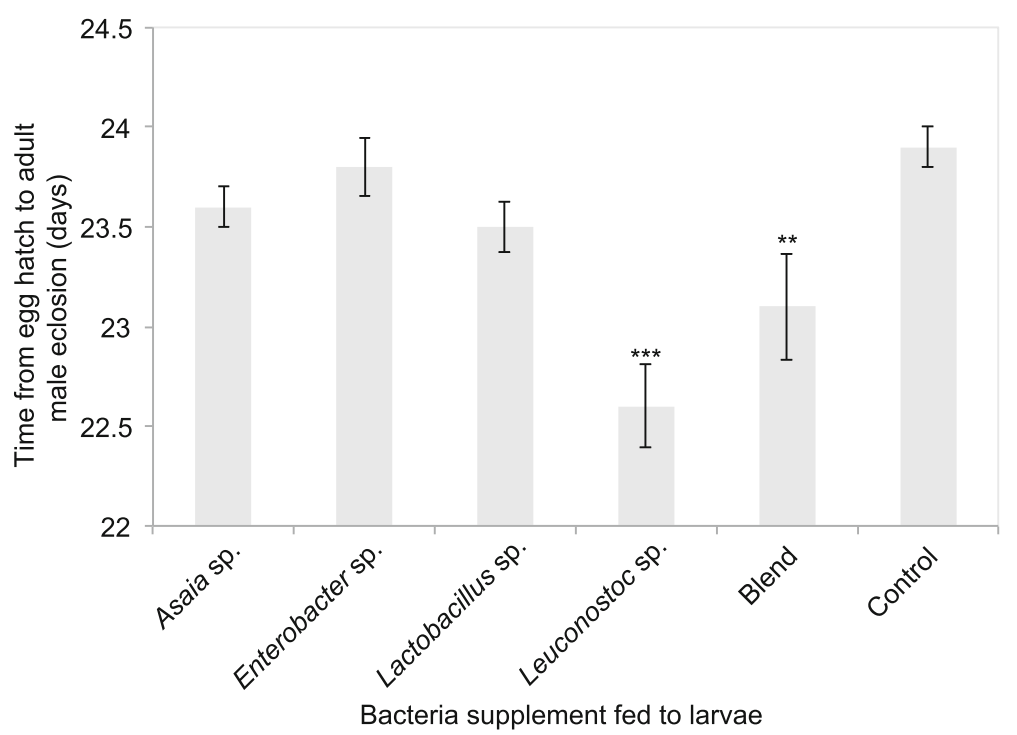

Fig. 5 Time (days) from egg hatch to adult eclosion of mass-reared male B. tryoni in days supplemented with various wild bacteria as larvae. Asterixes above columns indicate if the bacterial group is significantly different to the control within each day and the respective $p$-value $\left({ }^{*} p<0.05\right.$, ${ }^{*}$ $\left.p<0.01,{ }^{* * *} p<0.001\right)$ 


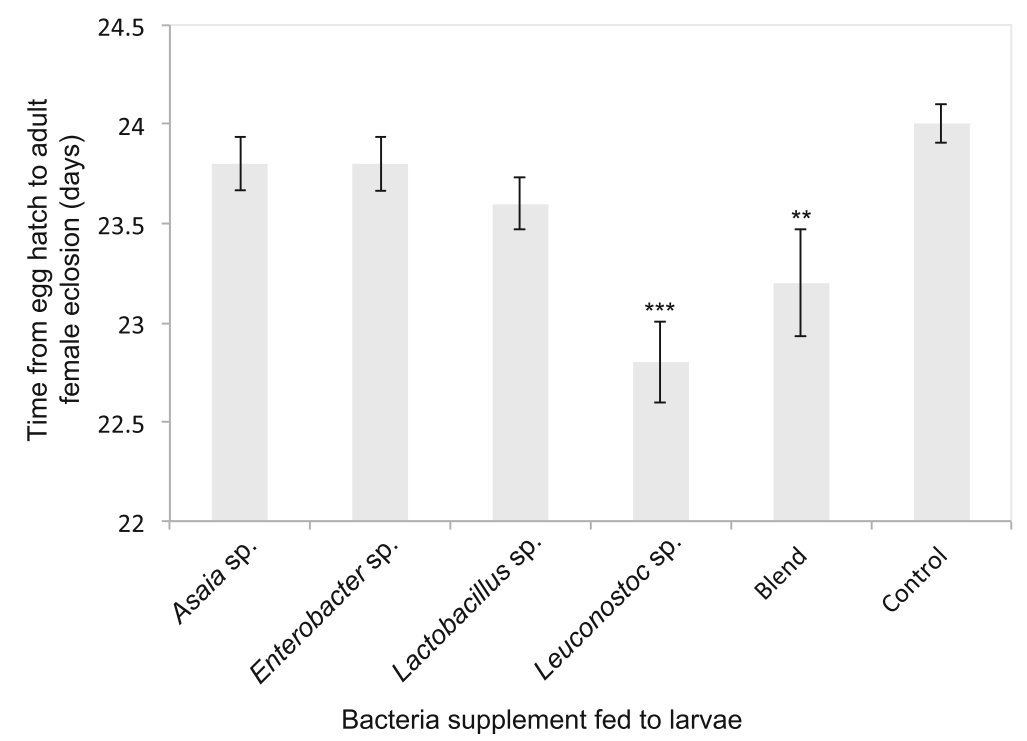

Fig. 6 Time (days) from egg hatch to adult eclosion of mass-reared female B. tryoni in days supplemented with various wild bacteria as larvae. Asterixes above columns indicate if the bacterial group is significantly different to the control within each day and the respective $p$-value $\left(^{*} p<0.05\right.$, ${ }^{* *} p<0.01$, *** $p<0.001$ )

\section{Sex ratio}

There was no deviation from the expected sex-ratio of $1: 1$ for males and females produced by any of the bacteria supplemented larval diets $(\mathrm{df}=25 \mathrm{~F}=0.486$ $p=0.782$ ) (Table 2).

\section{Discussion}

The present study demonstrated that wild bacteria supplemented larval B. tryoni influenced mass-reared larval development and adult eclosion, two parameters typically measured to assess the quality of flies used in SIT programs. The supplemented bacterial candidates were identified using near full-length $16 \mathrm{~S}$ sequencing and phylogenetics and selected based on their known associations in the gut of wild larval B. tryoni [19]. Additionally, a Lactobacillus strain was selected based on the known associations of this genus in a diversity of animal species including insects, birds, rodents and humans [17, 20-22]. The Enterobacter sp. and Asaia sp. strains reduced larval development time, while this was delayed by Lactobacillus sp., Leuconostoc sp. and the blend. Conversely, the time from egg hatch to adult eclosion was significantly reduced by Leuconostoc sp., and the blend in both males and females, suggesting that pupal development was accelerated by these supplements. This showed that the varying bacteria affected $B$. tryoni development at different developmental stages, depending on the strain or consortium, and is probably linked with their function in the fly. Reductions in development times have been observed in the Mediterranean fruit fly (Ceratitis capitata) after supplementation with a strain of Enterobacter sp. in the larval diet, particularly of males [6]. Reductions in the tephritid development periods can increase efficiencies in the mass-rearing process and are key in large scale SIT operational programs [18]. High levels of productivity and faster development translate into cost efficiencies including production of higher numbers of flies per generation and reduction of the space required for mass-rearing.

In the current study, B. tryoni larvae supplemented with bacteria did not impact pupal weight, emergence, flight ability or sex ratio. Conversely, Z. cucurbitae,

Table 2 Emergence and flight ability of adult Bactrocera tryoni fed bacteria supplements in the larval diet

\begin{tabular}{|c|c|c|c|c|}
\hline Bacteria group/combination & Mean emergence (\%) & Standard error & Mean fliers (\%) & Standard error \\
\hline Asaia sp. & $95 a$ & 2 & $91 a$ & 2 \\
\hline Enterobacter sp. & $98 a$ & 1 & $93 a$ & 4 \\
\hline Lactobacillus sp. & $98 a$ & 1 & $96 a$ & 2 \\
\hline Leuconostoc sp. & $98 a$ & 1 & $96 a$ & 1 \\
\hline Blend & $96 a$ & 1 & $93 a$ & 2 \\
\hline Control (no added bacteria) & $97 a$ & 1 & $93 a$ & 3 \\
\hline
\end{tabular}


Enterobacter sp. fed to larvae was found to increase pupal weight [7], and a study on C. capitata larvae supplemented with a blend of Citrobacter freundii, Enterobacter sp. and Klebsiella pneumoniae also found an increase in pupal weight [8]. Another study on $C$. capitata with larvae fed a single strain of Enterobacter sp. found no difference in pupal weight [6]. In our study, pupal weight across all bacterial groups were all lighter than the control, however they were all above the $10 \mathrm{mg}$ acceptable IAEA quality recommendation for $B$. tryoni [18]. In mass-reared B. tryoni, higher pupal weight has been found to be positively related to higher emergence and flight ability [23]. The three previously mentioned larval tephritid studies also analysed emergence and flight ability, and like the current study found no significant difference between the bacteria supplemented and control [6-8]. However there were effects on other parameters such as improved laboratory survival under water and food deprivation, increased adult fly size [7], and increased male mating competitiveness [8].

Previous tephritid bacterial supplementation assays have not included strains from the genera Asaia, Leuconostoc, and until recently Lactobacillus. Strains of Asaia are common insect symbionts [24] and have been shown to accelerate larval development of mosquitoes particularly by influencing the expression of host genes involved in cuticle formation [25, 26]. Strains in the genus Leuconostoc are not widely known from tephritids. In the few studies available they were identified from laboratoryreared and wild flies that were fed fruit at the larval stage [27-29]. Strains in the genus Lactobacillus affect several physiological and behavioural traits in tephritids and other Diptera. In a very recent study, Lactobacillus plantarum inoculated in to the larval diet of the tephritid Dacus ciliatus (cucurbit fly) was found to have negative effects on pupae production [17]. Conversely in Drosophila melanogaster, L. plantarum had positive effects including increased mating duration and induced higher short-term offspring production, and when fed to parent flies $L$. plantarum were reported to modulate body mass of female offspring [21]. This represented direct effects on adults as well as vertical effects. Further work is needed to fully elucidate the functional roles that probiotic bacteria have in tephritids.

The target bacteria were observed in the B. tryoni larval midguts by TEM after being fed the bacteria enriched carrot diet (Fig. 2), and the mean bacterial forming units isolated from larvae were higher when supplemented with both the individual bacteria and the consortium, compared to the control. A range of factors including $\mathrm{pH}$, temperature, colonisation resistance of the gut (resistance to colonisation by non-indigenous species thus preventing infections from potential pathogens), redox conditions, digestive enzymes present and competition between bacteria in the diet, and/or within the larvae after ingestion may explain some of the observed differences in colony forming units between the different bacterial groups [30]. Indeed, the relatively lower counts of Lactobacillus sp. in the individual and blend supplemented larvae is probably due, at least in part, to colonisation resistance, as Lactobacillus $\mathrm{sp}$. is a very minor component of the $B$. tryoni gut microbiome [19]. Enterobacter sp. appeared well adapted to the conditions and carrot diet used in the current experiment $\left(\mathrm{pH} 6,26^{\circ} \mathrm{C}\right)$. Similarly, the strain used proliferated in the larval gut, suggesting this environ is conducive to this bacteria. Most bacteria have an optimum pH 6-7 for growth, but several exceptions include lactic acid bacteria (e.g. Lactobacillus spp., Leuconostoc spp.) and acetic acid bacteria (e.g. Asaia spp). that can proliferate effectively under acidic environments [30] and are also likely to have different optimum temperatures for growth. Lactobacillus plantarum specifically has also been found to lower the $\mathrm{pH}$ of a tephritid larval diet from 5 to 4 after being added as a supplement [17]. Lactic acid bacteria and Asaia spp. are also common digestive tract associates of $B$. tryoni [19], and other insects including bees [31], beetles [32], mosquitoes [33, 34], and leaf hoppers [34]. Therefore in diets with low $\mathrm{pH}$ these bacteria would tend to proliferate quicker than those strains not adapted to low $\mathrm{pH}$. Citric acid is a component of the standard carrot diet used at the former FFPF (Fruit Fly Production Facility, NSW Department of Primary Industries, Menangle) and other facilities, reducing $\mathrm{pH}$ to 4.5 [35]. The $\mathrm{pH}$ of the carrot diet used in the current study was 6 due to the omission of citric acid. This omission was made as some of the added bacteria were expected to lower the $\mathrm{pH}$ further [17] and therefore impact the development and fitness of larvae. The present study was conducted under a constant temperature of $26^{\circ} \mathrm{C}$, which is the optimum temperature determined for B. tryoni mass-rearing [18]. This temperature may not be ideal for all of the bacterial strains added to the diet. Closely related bacterial species do grow effectively over a wide range of temperatures [36-39], however the optimum growth temperatures of individual strains used as mass rearing supplements will need to be determined. In the laboratory we observed the four wild bacterial strains grew faster in culture at $30^{\circ} \mathrm{C}$, rather than $26^{\circ} \mathrm{C}$. The use of bacterial supplements in mass-rearing will need to consider optimal $\mathrm{pH}$ and temperature as factors when selecting appropriate probiotics to incorporate at the mass-rearing scale. Similarly, compatible consortiums also warrant further study.

\section{Conclusions}

Bacteria fed to the larval stage of $B$. tryoni have scope to be administered as part of SIT programs to produce high quality insects. However, the selection of the bacterial strains is key as they each have specific effects, 
particularly on development time. Further studies need to address the effects of supplemented wild bacteria on other traits including survival and mating competitiveness of B. tryoni [40]. Ultimately, an understanding of the functional roles of individual bacterial strains in the insect gut and their use as larval probiotics, including as consortiums, is an area which requires increased focus, to better utilise and/or manipulate gut microbiota in pest management programs incorporating SIT.

\section{Methods}

Isolation of bacteria from wild B. tryoni larvae and culture deposit

Peaches infested with wild $B$. tryoni larvae were sourced from Redlands Research Station (RRS), Queensland. Infested apricots were sourced from Douglas Park, New South Wales. Individual third instar larvae had their midguts dissected and were lysed by hand with a sterile plastic mortar in $1 \mathrm{~mL}$ of sterile 1x Phosphate Buffered Saline (PBS). One hundred microliters of the resulting suspension was then spread on de Man, Rogosa and Sharpe agar (MRS; Becton, Dickinson and Company, MD, U.S.A.) and trytone soy agar (TSA; Becton, Dickinson and Company, MD, U.S.A.) plates in triplicate. Plates were incubated at $30^{\circ} \mathrm{C}$ for $2-3$ days. Single colonies were selected and subcultured on to MRS and TSA plates and incubated for $2-3$ days at $30^{\circ} \mathrm{C}$. Pure cultures were deposited at the New South Wales Plant Pathology Herbarium, Orange Agricultural Institute, New South Wales, Australia (DAR) (Table 3).

\section{Identification of bacterial isolates, RNA extraction, PCR, sequencing, phylogenetics and GenBank deposit}

Purified subcultures were grown in the dark at $25^{\circ} \mathrm{C}$ for 4 days on TSA (Asaia and Enterobacter) or MRS agar (Lactobacillus and Leuconostoc). RNA was extracted from a $5 \mathrm{~mm}^{3}$ sample of each isolate and placed in to $100 \mu \mathrm{L}$ of Extraction Buffer (Sigma Aldrich, Australia), homogenised by hand with a sterile plastic probe for 10 $\mathrm{s}$, then heated at $95^{\circ} \mathrm{C}$ for $5 \mathrm{~min}$. One hundred $\mu \mathrm{L}$ of Dilution Buffer (Sigma Aldrich, Australia) was then added. The 16S rRNA locus was selected for identifying the wild bacterial candidates to genus level. PCR amplification was performed in $10 \mu \mathrm{L}$ final volumes. The primer pairs for amplification were $\mathrm{FD} 1 / \mathrm{rP} 2$ or $\mathrm{FD} 2 / \mathrm{rP} 1$ [41].
Each reaction contained $5 \mu \mathrm{L} 2 \mathrm{x}$ MyTaq HS Mix (Bioline, Australia), $0.5 \mu \mathrm{L}$ of each primer and $3 \mu \mathrm{L}$ of sterile PCR grade water, and $1 \mu \mathrm{L}$ of template. The thermocycling conditions were as follows; one denaturation step of $5 \mathrm{~min}$ at $95^{\circ} \mathrm{C}$, followed by thirty five cycles of $30 \mathrm{~s}$ at $95^{\circ} \mathrm{C}, 30 \mathrm{~s}$ at $52^{\circ} \mathrm{C}$, and $45 \mathrm{~s}$ at $72^{\circ} \mathrm{C}$, followed by a final extension step of $5 \mathrm{~min}$ at $72^{\circ} \mathrm{C}$. Amplicons were visualised on a $1 \%$ agarose gel and sent to the Australian Genome Research Facility (Westmead, NSW) for Sanger sequencing using the same primer sets used in the amplification reactions. Sequences of reference taxa were sourced from GenBank. The alignment was completed with the MAFFT option of Geneious 7 (Biomatters, New Zealand) and edited manually. The phylogenetic tree was inferred using maximum parsimony in MEGA 7 [42]. Maximum parsimony bootstrap values $\geq 70 \%$ were placed at the nodes on the phylogenetic tree. Sequences generated in this study were deposited in GenBank under accessions MF370517-MF370520.

\section{Selection of bacterial candidates to feed to mass-reared larvae}

Bacterial candidates from the genera Asaia, Enterobacter, and Leuconostoc were selected based on their known associations in the gut of wild B. tryoni [4]. Additionally, a Lactobacillus isolate was selected based on the known gut associations strains in this genus have in a diversity of animal species including insects (eg. tephritids), birds, rodents and humans [17, 20-22]. A blend of all four of the individual bacteria was also included to observe any effects of increasing the diversity of wild bacteria fed to the larvae.

\section{Preparation of carrot diet enriched with wild bacteria}

Bactrocera tryoni larvae were reared on a standard diet comprising $338 \mathrm{~g}$ dehydrated carrot (bulking agent), $60 \mathrm{~g}$ of Torula yeast, $2.5 \mathrm{~g}$ sodium benzoate, and $600 \mathrm{ml}$ of water [35]. Ingredients were heated to $80^{\circ} \mathrm{C}$ for $5 \mathrm{~min}$, covered and left to cool to room temperature. The $\mathrm{pH}$ of the diet was 6. Live Asaia sp. and Enterobacter sp. cultures were grown on TSA plates, while the Lactobacillus sp. and Leuconostoc sp. cultures were grown on MRS agar plates for 3 days at $30^{\circ} \mathrm{C}$. The choice to use live bacteria in the larval diet was based on the observation of advantages of feeding live vs dead bacteria to

Table 3 Culture accessions of wild bacteria used as probiotics fed to B. tryoni larvae

\begin{tabular}{|c|c|c|c|}
\hline Species & Isolate & Location of collection & Host tree species \\
\hline Asaia sp. (Acetobacteriaceae, Proteobacteria) & DAR 83288 & Douglas Park, New South Wales & Prunus armeniaca (apricot) \\
\hline Enterobacter sp. (Enterobacteriaceae, Proteobacteria) & DAR 83287 & Redlands Research Station, Queensland & Prunus persica (peach) \\
\hline Lactobacillus sp. (Lactobacillaceae, Firmicutes) & DAR 83289 & Redlands Research Station, Queensland & Prunus persica (peach) \\
\hline Leuconostoc sp. (Leuconostocaceae, Firmicutes) & DAR 83290 & Redlands Research Station, Queensland & Prunus persica (peach) \\
\hline
\end{tabular}

DAR New South Wales Plant Pathology Herbarium, Orange Agricultural Institute, Orange, New South Wales, Australia 
tephritid larvae [6]. Loopfuls $\left(5 \mathrm{~mm}^{3}\right)$ of the Asaia and Enterobacter cultures were transferred to $30 \mathrm{~mL}$ sterile TSB, while the Lactobacillus and Leuconostoc cultures were transferred to $30 \mathrm{~mL}$ sterile MRS broth. Cultures were placed in a shaking incubator for $24 \mathrm{~h}$ at $30^{\circ} \mathrm{C}$ and $30 \mathrm{rpm}$. After incubation tubes were centrifuged for 5 mins at $4000 \mathrm{rpm}$. The broth supernatant was removed, and the pellet washed with $30 \mathrm{~mL}$ of PBS, and centrifuged for 5 mins at the same speed. The PBS supernatant was removed. Bacterial suspensions $1 \times 10^{8}$ colony forming units per $\mathrm{mL}$ were made in PBS. Colony forming units were determined via ocular density at 600 $\mathrm{nm}$ wavelength with a Versa Max microplate reader (Molecular Devices, California, U.S.A). Ocular densities and their corresponding colony forming units were determined with serial dilutions and plate counts. For washed bacteria suspended in PBS at a concentration of $1-2 \times 10^{8}$ colony forming units per $\mathrm{mL}$ the ocular densities were as follows: Asaia sp. $=0.1$, Enterobacter sp. $=$ 0.2 , Lactobacillus sp. $=0.2$, Leuconostoc sp. $=0.05$.

\section{Source of mass-reared B. tryoni eggs and conditions for laboratory-based experiments}

Mass-reared B. tryoni eggs were sourced from the FFPF, oviposited by 2 week-old adult flies raised on carrot diet (same ingredients as above except the addition of citric acid at $9 \mathrm{~g}$ per kilogram of diet). All laboratory based experiments were run at $26^{\circ} \mathrm{C} \pm 1{ }^{\circ} \mathrm{C}, 65 \% \pm 5 \%$ relative humidity, and 10:14 light:dark cycle.

\section{Larval development time}

Seventy-two rectangular plastic take away containers (500 $\mathrm{ml}$ volume) with lids were prepared. Lids of the plastic containers had a $5 \times 8 \mathrm{~cm}$ hole cut in the top, and a piece of white 'Swiss voile' polyester fabric $3 \mathrm{~cm}$ wider and longer than the container was placed under the lid to prevent the escape of larvae from the container. Thirty grams of autoclaved vermiculite was mixed with $60 \mathrm{ml}$ sterile water and added to the base of each container. The bacteria enriched carrot diet, and the carrot diet without bacteria (control) were weighed in to sterile $90 \mathrm{~mm}$ petri dishes. The agar plates with carrot diet were then placed over the vermiculite inside the takeaway containers. One hundred and fifty mass-reared $B$. tryoni eggs per replicate were randomly selected, twelve replicates per bacterial group. Circular black filter paper $90 \mathrm{~mm}$ in diameter was cut into quarters and autoclaved. Each quarter was moistened with $0.5 \mathrm{~mL}$ sterile water. One hundred and fifty eggs were placed on top of the moistened filter paper. Each quarter of filter paper containing eggs was then inverted, so that the eggs were in direct contact with the carrot diet in the agar plates. The lids of the agar plates were placed on top of the diet to maintain humidity during the egg hatch period. After 2 days, the lids were removed. Larval development time was measured from the time of egg hatch to the day of pupation by counting the number of pupae on each day of pupation until all larvae had pupated. All larvae pupated over a six-day period.

\section{Quantification of bacterial cells within mass-reared larvae after feeding wild bacteria}

Seven days after egg hatch (representing late third instar larvae) five individual larvae per bacterial group were surface disinfested in $70 \%$ ethanol for $1 \mathrm{~min}$, then rinsed in PBS. Larvae were transferred to $200 \mu \mathrm{L}$ PBS and homogenised by hand with a sterile plastic mortar. Serial dilutions were prepared $(10 \mathrm{X}, 100 \mathrm{X})$ of the original extract. Fifty microliters of the original extract and of each dilution were aliquoted on to a TSA plate for the Asaia, Enterobacter, blend and control groups, and an MRS plate for the Lactobacillus, Leuconostoc, blend and control groups. Plates were incubated at $30^{\circ} \mathrm{C}$ for $2-3$ days and the colonies that were morphologically identical (gram stain, cell morphology) to Asaia, Enterobacter, Lactobacillus and Leuconostoc were counted and subcultured. To confirm identification of colonies, representatives were selected and sequenced using the $16 \mathrm{~S}$ sequencing protocol previously described.

\section{Tranmission electron microscopy for visualising bacteria in mass-reared larval guts after feeding wild bacteria}

Larval midguts were cut into $2 \mathrm{~mm}$ sections and placed overnight in Karnovsky's fixative. Sections were rinsed in $1 \times$ PBS for $5 \mathrm{~min}$ (repeated three times) and placed in $1 \%$ buffered Osmium tetroxide for $4 \mathrm{~h}$ on a shaker. Sections were rinsed in deionized water for $5 \mathrm{~min}$ (repeated three times), immersed in $2 \%$ uranyl acetate for $1 \mathrm{~h}$, then dehydrated in an ethanol series starting from 30 to $100 \%$ and finally in acetone. Sections were immersed in 50\% acetone/Spurr's resin mixture and shaken for $1 \mathrm{~h}$, then fixed in pure resin and placed at $70^{\circ} \mathrm{C}$ for $30 \mathrm{~min}$, embedded in resin filled moulds, and polymerized overnight at $70{ }^{\circ} \mathrm{C}$. Resin blocks were trimmed and $70 \mathrm{~nm}$ sections placed on 300 mesh copper grids, stained with $2 \%$ uranyl acetate, followed by Reynold's lead citrate, washed in deionized water, and blot dried. Sections were visualised under a Philips 208 transmission electron microscope.

\section{Pupal weight}

Pupae were weighed individually 7 days after pupation, corresponding to the time that pupae in the FFPF are weighed for quality control purposes. Six replicates, each comprising 50 pupae per bacterial group were weighed, totalling three hundred pupae per bacterial group. 


\section{Emergence, flight-ability, and sex ratio}

One hundred and fifty pupae were selected with 6 replicates per bacterial group (total 900 pupae per bacterial group). Emergence and flight ability were calculated as mean percentages, and sex ratio was calculated as a ratio of the total pupae. Time to adult eclosion was determined by counting the number of adults (male and female) eclosing on each day for each bacterial group. Flight tubes were set up as in [18] with one flight tube containing one replicate placed in a single $30 \mathrm{~cm}^{3}$ mesh cage (Bugdorm, Taiwan). Fliers that escaped the flight tube were collected daily over 6 days, until no more flies left the flight tubes. The number of fliers, non-fliers, part-emerged, and deformed were recorded and sexed. Flight ability was calculated as the number of fliers of the total pupae per bacterial group.

\section{Adult eclosion}

One hundred and fifty pupae were selected, 6 replicates per bacterial group (total 900 pupae per bacterial group) and placed in $30 \mathrm{~cm}^{3}$ Bugdorm cages (one cage per replicate). Pupae were counted on each day of eclosion and sorted by sex. All adults eclosed over a six-day period.

\section{Statistical analyses}

R 3.3.3 [43] was used to analyse all data sets. A quasiPoisson Generalised Linear Model was applied to larval development time and adult eclosion data sets. A quasiBinomial model was applied to the emergence, flight ability, and sex ratio data sets. ANOVA was used to analyse the pupal weight data, and to test the quantification of bacterial cells within mass-reared larvae data (after $\log 10$ transformation). All analyses were tested against the non-bacteria supplemented control.

\section{Acknowledgements}

We acknowledge Ania Deutscher for providing bacterial cultures, and Brendan Missenden for sending B. tryoni infested peaches from Redlands Research Station, Qld.

\section{About this supplement \\ This article has been published as part of BMC Biotechnology Volume 19 Supplement 2, 2019: Proceedings of an FAO/IAEA Coordinated Research Project on Use of Symbiotic Bacteria to Reduce Mass-rearing Costs and Increase Mating Success in Selected Fruit Pests in Support of SIT Application: biotechnology. The full contents of the supplement are available online at https:// bmcbiotechnol.biomedcentral.com/articles/supplements/volume-19- supplement-2.}

\section{Authors' contributions}

LS conceptualised and completed the experiments, and wrote the article. MAMK helped conceptualise and complete the experiments, and wrote the article. TO helped conceptualise and complete the experiments. DC designed and completed the statistical analyses. MS completed and wrote the TEM component. OR conceptualised all of the experiments and wrote the article. All authors read and approved of the final manuscript.

\section{Funding}

This project has been funded by Hort Innovation using the summerfruit industry levy with co-investment from NSW Department of Primary Industries and funds from the Australian Government as part of the SITplus initiative. Hort Innovation is the grower owned, not-for-profit research and development corporation for Australian horticulture.

\section{Availability of data and materials}

The datasets used and/or analysed during the current study are available from the corresponding author on reasonable request.

\section{Ethics approval and consent to participate}

Not applicable.

\section{Consent for publication}

Not applicable.

\section{Competing interests}

The authors declare that they have no competing interests.

\section{Author details}

${ }^{1}$ Biosecurity and Food Safety, New South Wales Department of Primary Industries, Elizabeth Macarthur Agricultural Institute, Menangle 2568, Australia. ${ }^{2}$ Present address: NIAB EMR, Department of Pest and Pathogen Ecology, East Malling, Kent ME19 6BJ, UK. ${ }^{3}$ Department of Entomology, Faculty of Agriculture, Bangladesh Agricultural University, Mymensingh 2202, Bangladesh. ${ }^{4}$ Graham Centre for Agricultural Innovation (an alliance between NSW Department of Primary Industries and Charles Sturt University), Wagga Wagga, New South Wales 2650, Australia. ${ }^{5}$ State Key Laboratory of Ecological Pest Control for Fujian and Taiwan Crops, Institute of Applied Ecology, Fujian Agriculture and Forestry University, Fuzhou 350002, China. ${ }^{6}$ Present address: cesar Pty Ltd, Parkville, Victoria 3052, Australia.

Published: 18 December 2019

\section{References}

1. HIA. A fresh start for Australian horticulture. In: Annual Report. Horticulture Innovation Australia; 2015.

2. ISPM5. Glossary of phytosanitary terms. Rome: Food and Agriculture Organization of the United Nations, Rome; 2005.

3. Collins SR, Taylor PW. Fecundity, fertility and reproductive recovery of irradiated Queensland fruit fly Bactrocera tryoni. Physiol Entomol. 2011;36(3): 247-52.

4. Deutscher AT, Chapman TA, Shuttleworth LA, Riegler M, Reynolds OL. Tephritid-microbial interactions to enhance fruit fly performance in sterile insect technique programs. BMC Microbiol. 2019;19. (this special issue).

5. Fitt GP, O'Brien RW. Bacteria associated with four species of Dacus (Diptera: Tephritidae) and their role in the nutrition of the larvae. Oecologia. 1985; 67(3):447-54.

6. Augustinos AA, Kyritsis GA, Papadopoulos NT, Abd-Alla AMM, Cáceres C, Bourtzis K. Exploitation of the medfly gut microbiota for the enhancement of sterile insect technique: use of Enterobacter sp. in larval diet-based probiotic applications. PLoS One. 2015;10(9):e0136459.

7. Yao M, Zhang H, Cai P, Gu X, Wang D, Ji Q. Enhanced fitness of a Zeugodacus cucurbitae (syn: Bactrocera cucurbitae) genetic sexing strain based on the addition of gut-isolated probiotics (Enterobacter spec.) to the larval diet. Entomol Exp Appl. 2016;162:197-202.

8. Hamden H, Guerfali MM, Fadhl S, Saidi M, Chevrier C. Fitness improvement of mass-reared sterile males of Ceratitis capitata (Vienna 8 strain) (Diptera: Tephritidae) after gut enrichment with probiotics. J Econ Entomol. 2013; 106(2):641-7.

9. Jurkevitch E. Riding the Trojan horse: combating pest insects with their own symbionts. Microb Biotechnol. 2011;4(5):620-7.

10. Ben-Ami E, Yuval B, Jurkevitch E. Manipulation of the microbiota of mass-reared Mediterranean fruit flies Ceratitis capitata (Diptera: Tephritidae) improves sterile males sexual performance. Int Soc Microb Ecol. 2010;4:28-37.

11. Gavriel S, Gazit Y, Jurkevitch E, Yuval B. Bacterially enriched diet improves sexual performance of sterile male Mediterranean fruit flies. J Appl Entomol. 2011;135:564-73.

12. Sacchetti P, Ghiardi B, Granchietti A, Stefanini FM, Belcari A. Development of probiotic diets for the olive fly: evaluation of their effects on fly longevity and fecundity. Ann Appl Biol. 2014;164(1):138-50. 
13. Behar A, Jurkevitch E, Yuval B. Bringing back the fruit into fruit fly-bacteria interactions. Mol Ecol. 2008;17(5):1375-86.

14. Behar A, Yuval B, Jurkevitch E. Gut bacterial communities in the Mediterranean fruit fly (Ceratitis capitata) and their impact on host longevity. J Insect Physiol. 2008;54(9):1377-83.

15. Ben-Yosef $M$, Pasternak Z, Jurkevitch E, Yuval B. Symbiotic bacteria enable olive fly larvae to overcome host defences. R Soc Open Sci. 2015;2(7):150170.

16. Cheng D, Guo Z, Riegler M, Xi Z, Liang G, Xu Y. Gut symbiont enhances insecticide resistance in a significant pest, the oriental fruit fly Bactrocera dorsalis (Hendel). Microbiome. 2017;5(13):1-12.

17. Rempoulakis P, Sela S, Nemny-Lavy E, Pinto R, Birke A, Nestel D. Microbial composition affects the performance of an artificial Tephritid larval diet. Bull Entomol Res. 2017;13:1-8.

18. FAO/IAEA/USDA. Product quality control for sterile mass-reared and released tephritid fruit flies, version 6.0. Vienna: International Atomic Energy Agency; 2014. p. 23-7.

19. Deutscher AT, Burke CM, Darling AE, Riegler M, Reynolds OL and Chapman TA. Near full-length $16 \mathrm{~S}$ rRNA gene nextgeneration sequencing revealed Asaia as a common midgut bacterium of wild and domesticated Queensland fruit fly larvae, 2018;6:85. https://doi.org/10.1186/s40168-018-0463-y.

20. Stevenson C, Blaauw R, Fredericks E, Visser J, Roux S. Randomized clinica trial: effect of Lactobacillus plantarum 299 von symptoms of irritable bowel syndrome. Nutrition. 2014;30:7.

21. Morimoto J, Simpson SJ, Ponton F. Direct and trans-generational effects of male and female gut microbiota in Drosophila melanogaster. Biol Lett. 2017; 13(7):20160966.

22. Million M, Angelakis E, Paul M, Armougom F, Leibovici L, Raoult D. Comparative meta-analysis of the effect of Lactobacillus species on weight gain in humans and animals. Microb Pathog. 2012;53(2):100-8.

23. Dominiak BC, Sundaralingam S, Jiang L, Jessup AJ, Barchia IM. Production levels and life history traits of mass reared Queensland fruit fly Bactrocera tryoni (Froggatt) (Diptera: Tephritidae) during 1999/2002 in Australia. Plant Protection Quarterly. 2008;23(3):131-5.

24. Crotti E, Damiani C, Pajoro M, Gonella E, Rizzi A, Ricci I, Negri I, Scuppa P, Rossi P, Ballarini P, et al. Asaia, a versatile acetic acid bacterial symbiont, capable of cross-colonizing insects of phylogenetically distant genera and orders. Environ Microbiol. 2009;11:3252-564.

25. Mitraka E, Stathopoulos S, Siden-Kiamos I, Christophides GK, Louis C. Asaia accelerates larval development of Anopheles gambiae. Pathogens Glob Health. 2013;107:305-11.

26. Chouaia B, Rossi P, Epis S, Mosca M, Ricci I, Damiani C, et al. Delayed larval development in Anopheles mosquitoes deprived of Asaia bacterial symbionts. BMC Microbiol. 2012;12(Suppl 1):S2

27. Thaochan N, Drew RAl, Chinajariyawong A, Sunpapao A, Pornsuriya C. Gut bacterial community structure of two Australian tropical fruit fly species (Diptera: Tephritidae). Songklanakarin J Sci Technol. 2015;37(6):617-24.

28. Yao Z, Wang A, Li Y, Cai Z, Lemaitre B, Zhang H. The dual oxidase gene BdDuox regulates the intestinal bacterial community homeostasis of Bactrocera dorsalis. ISME J. 2016:10:1037-50.

29. Thaochan N, Drew RAl, Hughes JM, Vijaysegaran S, Chinajariyawong A. Alimentary tract bacteria isolated and identified with API-20E and molecular cloning techniques from Australian tropical fruit flies, Bactrocera cacuminata and B. tryoni. J Insect Sci. 2010;10:131.

30. Dillon RJ, Dillon VM. The gut bacteria of insects: nonpathogenic interactions. Annu Rev Entomol. 2004:49:71-92.

31. Corby-Harris $V$, Maes $P$, Anderson KE. The bacterial communities associated with honey bee (Apis mellifera) foragers. PLoS One. 2014;9(4):e95056.

32. Wielkopolan B, Obrępalska-Stęplowska A. Three-way interaction among plants, bacteria, and coleopteran insects. Planta. 2016;244:313-32.

33. Favia G, Ricci I, Damiani C, Raddadi N, Crotti E, Marzorati M, et al. Bacteria of the genus Asaia stably associate with Anopheles stephensi, an Asian malarial mosquito vector. Proc Natl Acad Sci. 2007;104(21):9047-51.

34. Crotti E, Rizzi A, Chouaia B, Ricci I, Favia G, Alma A, et al. Acetic acid bacteria, newly emerging symbionts of insects. Appl Environ Microbiol. 2010;76(21):6963-70

35. Jessup AJ. Production quality assurance for tri-state sterile insect research program. In: Horticultural Research and Development Corporation, Australia; 1999.

36. Suzuki RZY, lino T, Kosako Y, Komagata K, Uchimura T. Asaia astilbes sp. nov., Asaia platycodi sp. nov., and Asaia prunellae sp. nov., novel acetic acid bacteria isolated from flowers in Japan. J Gen Appl Microbiol. 2010;56(4):339-46.
37. Farrow JAE, Facklam RR, Collins MD. Nucleic acid homologies of some vancomycin-resistant Leuconostocs and description of Leuconostoc citreum sp. nov. and Leuconostoc pseudomesenteroides sp. nov. Int J Syst Evol Microbiol. 1989:39:279-84.

38. Peterson CS. A study of the species Lactobacillus plantarum (Orla-Jensen) Bergey et al. J Bacteriol. 1936;31(3):217-24.

39. Grimont PAD, Grimont F. Enterobacter. In: Bergey's manual of systematics of Archaea and Bacteria. Hoboken: Wiley; 2015.

40. Shuttleworth LA, Abul Monjur Khan M, Collins D, Osborne T and Reynolds OL. Wild bacterial probiotics fed to larvae of mass-reared Queensland fruit fly [Bactrocera tryoni (Froggatt)] do not impact long-term survival, mate selection, or locomotor activity. Insect Science. 2019;00:1-11. https://doi.org/ 10.1111/1744-7917.12670.

41. Weisburg WG, Barns SM, Pelletier DA, Lane DJ. 165 ribosomal DNA amplification for phylogenetic study. J Bacteriol. 1991;173(2):697-703.

42. Kumar S, Stecher G, Tamura K. MEGA7: molecular evolutionary genetics analysis version 7.0 for bigger datasets. Mol Biol Evol. 2016;33(7):1870-4.

43. Urbanek S, Bibiko H-J. R.app GUI 1.69 (7328 mavericks build). In: R Foundation for statistical computing; 2016.

\section{Publisher's Note}

Springer Nature remains neutral with regard to jurisdictional claims in published maps and institutional affiliations.
Ready to submit your research? Choose BMC and benefit from:

- fast, convenient online submission

- thorough peer review by experienced researchers in your field

- rapid publication on acceptance

- support for research data, including large and complex data types

- gold Open Access which fosters wider collaboration and increased citations

- maximum visibility for your research: over $100 \mathrm{M}$ website views per year

At $\mathrm{BMC}$, research is always in progress.

Learn more biomedcentral.com/submissions 